\title{
Characterization of Cassia Tora Seed (CTS) Oil-Based Biodiesel-Diesel Blends
}

\section{Saferiel Onatola Morakinyo ${ }^{1}$, Umar Omeiza Aroke ${ }^{2}$, Jibril Mohammed ${ }^{2}$, Idris Misau Muhammad ${ }^{2}$, Abdulwadud Abdulkarim Yusuf ${ }^{2}$}

\author{
${ }^{1}$ Kaduna Refining and Petrochemical Company \\ KM 16 Kachia Road, P. M. B 2252, Kaduna, Nigeria \\ ${ }^{2}$ Abubakar Tafawa Balewa University \\ Tafawa Balewa Way, P. M. B. 0248, Bauchi, 740272, Nigeria
}

DOI: $10.22178 /$ pos.66-3

LCC Subject Category: SB1-1110

Received 22.11.2020

Accepted 26.01.2021

Published online 31.01.2021

Corresponding Author:

Abdulwadud Abdulkarim Yusuf

aabdulwadud@atbu.edu.ng

(C) 2020 The Authors. This article is licensed under a Creative Commons Attribution 4.0 License @ (1)

\begin{abstract}
The paper reported on the characterization of CTS oil-based biodieseldiesel blends. The study's primary objective are the physicochemical characterization of oil and biodiesel from Cassia Tora seed (CTS) oil, characterization of CTS oil-based biodiesel using FTIR and GCMS analysis. Extraction revealed the presence of $8.8 \%$ oil in Cassia Tora seed. The CTS biodiesel's viscosity was found to be 0.9092 , which is well above the petroleum diesel.

The physiochemical characterization showed that 5, 12.5 and $20 \%$ CTS oil-based biodiesel-diesel blends are within acceptable limit for combustion engine without modification having viscosities of $0.8744,0.8764$, and 0.8787 respectively while $100 \%$ CTS oil-based biodiesel would require upgrading to meet up with the recommended standard for fuel used as diesel in internal combustion engines.

FTIR and GCMS analysis showed functional groups and characteristic peaks of fatty acids and methyl ester with carbon range from $\mathrm{C}_{13}-\mathrm{C}_{17}, \mathrm{C}_{16}$ constituted the major Fatty acid group and contained $61.69 \%$ Monounsaturated Fatty Acid (MUFA), and $38.31 \%$ Saturated Fatty Acid (SFA) giving a $94.3 \%$ biodiesel yield.
\end{abstract}

Keywords: characterization; oil; blends; diesel; physiochemical; biodiesel; fatty acid; cassia tora; seed.

\section{INTRODUCTION}

The chief chemical constituents of Cassia Tora include cinnamaldehyde, gum, tannis, mannitol, coumarins, and essential oils. Phytochemical analyses of Cassia plant extracts and callus extracts contain anthrone, flavonoids, glycoside, and anthracene derivatives. The leaves have approximately $72 \%$ water, $10 \%$ petroleum ether extract, $0.90 \%$ ether extract, $1.60 \%$ absolute alcohol extract and $20 \%$ watery extract. It also contains sugars, resins, and mucilage, among other constituents [20].

The plant as a whole and specific parts such as the roots, leaves and seeds have been widely used in traditional Indian and South Asian medicine [3]. The plant's edible amount varies from 30 to $40 \%$, and the young leaves can be cooked as a vegetable while the roasted seeds could serve a good substitute for coffee and its flowers are added to food in Sri Lanka [3]. It is used as a natural pesticide in organic farms, and its powder is most commonly used in the pet food industry, and it is mixed with guar gum for use in mining and other industrial applications. The seeds and leaves are also used for skin disease treatment, and its sources can be utilized as a laxative. In the Republic of Korea, it is believed to rejuvenate human vision. The tea is believed to have created a new term "coffee-tea", because of its weird but vibrant taste and its coffee aroma. The tea is made from $100 \%$ Cassia Tora, with no artificial colouring and no caffeine, and could be a healthier substitute for coffee and sodas. It has been used to treat skin diseases such as leprosy, ringworm, itching and psoriasis, and snakebites due to its external germicide and antiparasitic character [3].

Cassia Tora seed is one of the oil seeds discovered worldwide [18]. The choice of oil-yielding plant species depends mainly on a thorough understanding of cultivation characteristics like soil 
character, salt content, nature and content of organic matter, and $\mathrm{pH}$ that influence the plant's oil yield. But the overall suitability of extracted crude vegetable oils for technical purposes, the acquaintance of oil content, physical properties, and oils' chemical properties are essential.

With the advent of cheap petroleum, appropriate crude oil fractions were refined to fuel while diesel fuels and diesel engines evolved together. Between 1930-1940 vegetable oils were used as diesel fuels but usually only in emergencies. Due to crude oil prices, limited resources of fossil oil and environmental concerns, there has been a renewed focus on vegetable oils and animal fats to make biodiesel fuels. Continued and increasing use of petroleum will intensify local air pollution and magnify the global warming problems caused by $\mathrm{CO}_{2}$. In a particular case, such as the emission of pollutants in the closed environments of underground mines, biodiesel fuel has the potential to reduce the level of contaminants and the level of potential or probable carcinogens [17].

Currently the industrial biodiesel production bases almost exclusively on the chemical trans-esterification of triglycerides (TAGs) from vegetable oils employing methanol. However, other shortchain alcohols like ethanol, propanol could be used as well [16]. Among all the feedstock vegetable oils (both edible and non-edible) are a most promising feedstock for the biodiesel production since they are renewable and can be produced in large scale. Still, the use of edible oil as feedstock may cause some problems such as the competition with the edible oil market, which increases both the cost of edible oils and biodiesel. To overcome these disadvantages, most of the research focuses on non-edible oils that are not suitable for human consumption because of some toxic oil components.

\section{MATERIALS AND METHODS}

Materials used for this finding are Cassia Tora Seeds, reagents and apparatus/equipment. The seeds were collected at different locations within Bauchi town.

All chemicals and solvents used were analytical grades from Sigma Aldrich, England. These are acetone, chloroform, concentrated sulfuric acid, diethyl ether, ethyl acetate, ethanol, hydrochloric acid, iodine monochloride, n-hexane, petroleum ether, phenolphthalein, potassium hydroxide, sodium hydroxide, sodium thiosulphate.
The apparatus and equipment used in this study are test tubes, measuring cylinders, $500 \mathrm{ml}$ round bottom flasks, reflux condensers, $250 \mathrm{ml}$ beakers, $50 \mathrm{ml}$ pipette, $5 \mathrm{ml}$ micro burette, paper filter (1.0 mm), Soxhlet extractor, separator funnel,100 ml burette, spatula, dropper, stirring bit, and other related glasswares. Weighing balance (Melrose pack, Illinois), Gallen Kamp magnetic stirrer, gladden viscometer, Corning $\mathrm{pH}$ meter, Bellingham refract meter, Copenhagen digital temperature measurement, Smith stopwatch, TD114 instrumentation unit, TD115 hydraulic dynamometer, GC-MS Shimadzu QP500, RE-52A rotary evaporator, and Madison WI thermo Nicolet analytical instrument.

\section{Methods}

1) Cassia Tora Seed Oil extraction (adopted by [22]). Cassia Tora Seeds were ground to obtain $0.037-2.0 \mathrm{~mm}$ for proper extraction. $80 \mathrm{~g}$ of the ground sample was packed in a paper filter and inserted into the soxhlet extractor used is petroleum ether was used as a solvent. $500 \mathrm{~cm}^{3}$ of the solvent was used on $80 \mathrm{~g}$ of the sample for six hours of extraction. At the end of successful extraction, the solvent was recovered using a rotary evaporator. The residual oil was oven-dried at $105{ }^{\circ} \mathrm{C}$ for one hour before the sample was weighed for further experimentation.

2) Esterification and trans-esterification. Optimum values for Cassia tora free fatty acid reduction (Esterification) and Cassia tora biodiesel production (trans-esterification) was adopted by [22]. In esterification, the high FFA of CTO was reduced by its pretreatment with methanol/oil ratio (6:1), H2SO4 catalyst $(1.6 \mathrm{v} / \mathrm{v})$ in $93 \mathrm{~min}$ at $45^{\circ} \mathrm{C}$ while the trans-esterification Cassia Tora biodiesel was produced using methanol/oil molar ratio (9:1), $\mathrm{NaOH}$ catalyst $(0.8 \mathrm{w} / \mathrm{w})$ in $120 \mathrm{~min}$ at $50{ }^{\circ} \mathrm{C}$.

3) Gas Chromatography-Mass Spectrometry (GCMS). For GC-MS analysis, $100 \mathrm{~L}$ of oil biodiesel was dissolved in $2 \mathrm{~mL}$ of dichloromethane (DCM). The sample was analyzed on a Shimadzu GC-MS system model QP500 with a medium polarity capillary column (BPX-5 column (29.4 $\mathrm{m}$ by $0.25 \mathrm{~mm}$ ). The film thickness of $0.25 \mathrm{~m}$ ) with helium as the carrier gas. One microliter of the sample was injected using splitless injection with injector temperature $300^{\circ} \mathrm{C}$ according to a scheme of $50^{\circ} \mathrm{C}$ for $2 \mathrm{~min}$ with $10^{\circ} \mathrm{C} / \mathrm{min}$ up to a maximum temperature of $300{ }^{\circ} \mathrm{C}$. The final temperature was held for 
$10 \mathrm{~min}$. The total runtime for each sample was $37 \mathrm{~min}$. For MS detection, electron ionization with $70 \mathrm{eV}$ was applied, and mass fragments were detected between 40 and $500 \mathrm{~m} / \mathrm{z}$. The ion source temperature and transfer line temperature were $200{ }^{\circ} \mathrm{C}$ and $300^{\circ} \mathrm{C}$, respectively, after the detector was activated for $5 \mathrm{~min}$.

4) Fourier Transform Infrared (FTIR). All spectra were obtained using an ATR-FTIR of Thermo Scientific (Thermo Nicolet Analytical Instruments, Madison, WI). The spectra were collected at a resolution of $4 \mathrm{~cm}^{-1}$ in the range of $4000-650 \mathrm{~cm}^{-1}$. Each spectrum was rationed against a fresh background spectrum recorded from the bare ATR crystal. Before collecting each background spectrum, the ATR crystal was cleaned with absolute ethanol to remove any residual. Each sample was scanned in triplicate.

5) Biodiesel-diesel blends formulation. To establish blends for diesel engine performance investigation, biodiesel-petroleum diesel fuels were blended by mixing the biodiesel and diesel in different proportions using an in-tank blending method. The most common biodiesel-diesel blends were in the range of 2-30\% biodiesel (i.e. B2-B30) [6]. Many diesel engine original equipment manufacturers (OEMs) approve blends in the range of $2-30 \%$ on the engine without modifications [1]. On this basis, the blend ratios in this report were set within the feasible range (2$30 \%$ ) of biodiesel blend for the combustion and engine performance analysis

6) Physicochemical characterization of Cassia Tora biodiesel-diesel blends. The various blended biodiesel-petroleum diesel was characterized for the combustion and performance characteristics such as kinematic viscosity, specific gravity, flash point, pour point, heating value, fuel consumption analysis, and power rating analysis determining their suitability for use in the diesel engine.

Knowing the saponification and iodine value of the various biodiesel-diesel blends produced, using the correlation given by [21], each blend's cetane number was calculated using equations (1)(3).

$$
\begin{aligned}
& \text { Cetane Number }(C N)= \\
& \quad=46.3+\left(\frac{5458}{S V}\right)-(0.225 x I V)
\end{aligned}
$$

Saponification Value $(S V)=$

$$
=\left(\frac{56.1 \times B-A \times N}{\text { weight of oil sample used }}\right)
$$

$$
\text { Iodine Value }(I V)=\left(\frac{(B-A) \times 100 \times 126.9 \times 2)}{(100 \times W)}\right)
$$

where B - the volume of standard ethanol potassium hydroxide used in blank titration;

A - volume of standard ethanol potassium hydroxide used in biodiesel titration;

$\mathrm{N}$ - normality of standard acid used in the titration;

$\mathrm{W}$ - the weight of the oil sample.

Flashpoint analyzer was used for the test. The biodiesel blend was poured into the analyzer copper container to the prescribed mark, and the cover fitted to its position. Heating was carried out using Bunsen burner at the same time stirring of the sample follows, and the temperature at which a clean flash occurred was recorded as the flashpoint.

Kinematic viscosity was carried out using the NDJ$5 S$ Digital Rotary Viscometer and the DBK Mini Magnetic Stirrer/Heater. The biodiesel blend was placed in beakers and the beaker placed on the heater with the viscometer's piston placed inside it. As the piston of the viscometer rotates in the beaker and the biodiesel blend heated. A thermometer placed at the beaker's side to monitor temperature and readings was taken from the viscometer at $40{ }^{\circ} \mathrm{C}$ and $100{ }^{\circ} \mathrm{C}$ [23]. The same procedure was repeated for all other blend samples.

Pour point test was carried out in the laboratory using a bath, test tubes and a negative thermometer. Measured quantities of B5, B12.5 and B20 biodiesel blend samples were poured into a medium-sized test tube and placed in the ice bath. The temperatures were checked periodically at 30-sec intervals for flow characteristics with the thermometer to check for the temperature. The temperature at which the B5, B12.5 and B20 biodiesel blend samples start to coagulate was determined as its pour point [23]. The same procedure was repeated for all other instances.

$10 \mathrm{~cm}^{3}$ of the biodiesel blend was measured in a pre-weighed measuring cylinder. The cylinder and biodiesel blend's weight was measured; the biodiesel blend's importance was obtained by subtracting the cylinder's weight from the weight of the biodiesel blend and cylinder. The specific gravity of the biodiesel blend was obtained using equations (4)-(6) by [23]. 


$$
\rho_{\text {water }}=\frac{W_{1}-W_{0}}{V_{0}}
$$

where $\mathrm{W}_{1}$ = weight of measuring cylinder + water; $\mathrm{W}_{0}=$ weight of empty measuring cylinder;

$\mathrm{V}_{1}=$ volume of water used.

$$
\rho_{\text {blend }}=\frac{W_{2}-W_{0}}{V_{2}},
$$

where $\mathrm{W}_{2}=$ weight of measuring cylinder + biodiesel blend;

$\mathrm{V}_{2}=$ volume of biodiesel blend.

$$
\text { Specific gravity }=\frac{\rho_{\text {blend }}}{\rho_{\text {water }}} \text {. }
$$

The calorific value is the measurement of heat or energy produced and is measured either as gross calorific value or net calorific value. The calorific values were obtained from a survey of diesel fuel and biofuels.

\section{RESULTS AND DISCUSSION}

Oil extracted from CTS was used for biodiesel production with the aid of Soxhlet apparatus and petroleum ether solvent with an oil yield of $8.8 \%$. Optimized values of the process variables used in the esterification (reduction of FFA in oil) and transesterification reaction are presented in Table 1 .

Table 1 - Optimized values of Process variables for esterification and transesterification reaction

\begin{tabular}{|l|c|c|c|c|c|}
\hline Reaction & $\begin{array}{c}\text { Methanol Oil Ration } \\
(\mathrm{v} / \mathrm{v})\end{array}$ & $\begin{array}{c}\text { Catalyst } \\
(\mathrm{w} / \mathrm{w})\end{array}$ & $\begin{array}{c}\text { Temperature } \\
\left({ }^{\circ} \mathrm{C}\right)\end{array}$ & $\begin{array}{c}\text { Reaction time } \\
(\mathrm{min})\end{array}$ & Value \\
\hline Esterification & 6 & 1.6 & 45 & 93 & $\begin{array}{c}\text { FFA: } 0.38 \\
\text { mgKOH/g }\end{array}$ \\
\hline $\begin{array}{l}\text { Transesterifi- } \\
\text { cation }\end{array}$ & 9 & 0.8 & 50 & 120 & $\begin{array}{c}\text { Biodiesel yield: } \\
94.3 \%\end{array}$ \\
\hline
\end{tabular}

These optimum process parameters used (methanol-oil ratio of $6: 1$, acid catalyst of $1.6 \mathrm{v} / \mathrm{v}$ and 93 min reaction time) for esterification of the CTS oil and, the methanol-oil ratio of 9:1, the base catalyst of $0.8 \mathrm{v} / \mathrm{v}$ and $12 \mathrm{~min}$ reaction time for biodiesel production were adopted from [22]. Validation experiments were conducted to yalidate the reliability of the optimum parameters established by [22] for maximum yield. Table 1 presents the result obtained from the validation study for esterification and transesterification of CTS oil.

Table 1 observed that the FFA of the CTS oil was reduced to $0.38 \mathrm{mg} \mathrm{KOH} / \mathrm{g}$ from initial value of 2.5 $\mathrm{mg} \mathrm{KOH} / \mathrm{g}$ due to esterification pretreatment of the CTS oil which is comparable to $0.395 \mathrm{mg}$ $\mathrm{KOH} / \mathrm{g}$ FFA reported by [22] for CTS oil.

This reduction is necessary because high FFA in oil reduced process efficiency of the oil for biodiesel production as it will lead to saponification reaction and decreases yield during biodiesel production, as such oil used for biodiesel product should have FFA $<0.5 \mathrm{mg} \mathrm{KOH} / \mathrm{g}$ (FFA $<1 \%$ ) [9, 13]. It was also found that $94.3 \%$ biodiesel yield was obtained from transesterification of CTS oil with methanol at the catalyst presence's optimum parameter. The $94.3 \%$ biodiesel yield obtained from the validation study compared favourably with $95.9 \%$ reported by [22]. The high biodiesel yield from the pretreated oil could be attributed to reducing the FFA content in the oil to FFA $<0.5 \mathrm{mg}$ $\mathrm{KOH} / \mathrm{g}[13,15]$. The validation study showed that the optimum parameter reported by [22] is reliable.

\section{Fourier transforms infrared spectroscopy analysis}

The FTIR is a measure of the quantitative and qualitative analysis of the functional group of organic and inorganic samples. The FTIR spectrum for the extracted oil is shown in Figure 1, and the result obtained from the transmittance spectrums is presented in Table 2. From the FTIR impact obtained, as shown in Table 2, the constituent functional groups of the extracted CTS oil are mainly, carboxylic, carbonyl, aliphatic and hydroxyl functional groups of ester and carboxylic acids. The peaks obtain from the FTIR analysis are shown in Figure 1. 


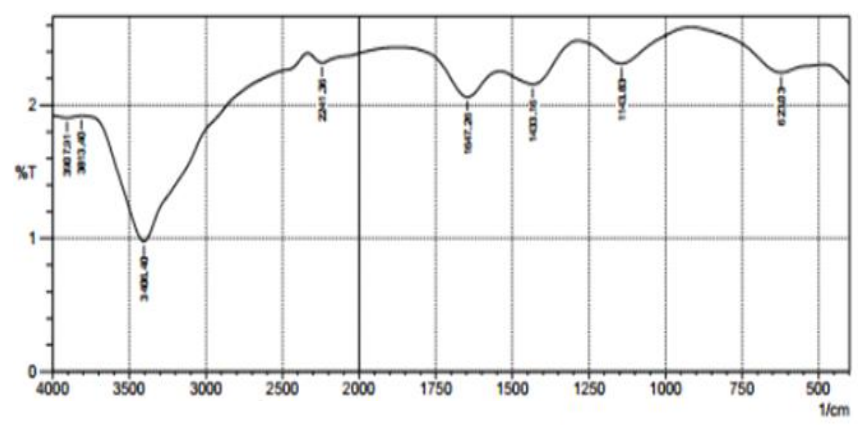

Figure 1 - FTIR spectrum of Cassia Tora Oil

The prominent absorption peaks identified from Figure 1 are correlated with their respective functional group vibration modes, as shown in Table 2.

Table 2 - FTIR functional group of the extracted CTS oil

\begin{tabular}{|l|l|l|l|}
\hline No & $\begin{array}{c}\text { Absorption } \\
\text { band }\end{array}$ & $\begin{array}{l}\text { Vibrational } \\
\text { mode }\end{array}$ & $\begin{array}{l}\text { Functional group } \\
\text { description }\end{array}$ \\
\hline $\mathbf{1}$ & 623 & $\mathrm{C}=\mathrm{C}$ & $\begin{array}{l}\text { Out of plane } \\
\text { vibration of cis - } \\
\text { distributed olefins }\end{array}$ \\
\hline $\mathbf{2}$ & 1143 & $\mathrm{C}-\mathrm{O}$ & $\begin{array}{l}\text { Of carboxylic ester } \\
\text { group }\end{array}$ \\
\hline $\mathbf{3}$ & 1433 & $\mathrm{C}-\mathrm{H}$ & $\begin{array}{l}\text { Bending vibrations } \\
\text { of } \mathrm{CH}_{3} \text { and CH2 } \\
\text { aliphatic carbon } \\
\text { chains }\end{array}$ \\
\hline $\mathbf{4}$ & 1647 & $\mathrm{C}=\mathrm{O}$ & $\begin{array}{l}\text { Carbonyl group in } \\
\text { carboxylic acid and } \\
\text { esters }\end{array}$ \\
\hline $\mathbf{5}$ & 2241 & $\mathrm{C}=\mathrm{C}$ & $\begin{array}{l}\text { Unsaturation on } \\
\text { carbon chain }\end{array}$ \\
\hline $\mathbf{6}$ & 3406 & O- H & $\begin{array}{l}\text { Hydroxyl group of } \\
\text { carboxylic acids }\end{array}$ \\
\hline $\mathbf{7}$ & $\begin{array}{l}3813, \\
3907\end{array}$ & O-H & $\begin{array}{l}\text { Interstitial } \\
\text { hydrogen bonding. }\end{array}$ \\
\hline
\end{tabular}

Correlating the absorption bands in the FTIR spectra that were obtained, the absorption peaks in the region of $3400 \mathrm{~cm}^{-1}$ is assigned to $0-\mathrm{H}$ bond, $1647 \mathrm{~cm}^{-1}$ to $\mathrm{C}=0$ bond, $1143 \mathrm{~cm}^{-1}$ to the $\mathrm{C}-0$ bond are indicative of the distinctive feature of the carboxylate and ester groups $(\mathrm{COOH})$ which is the characteristic functional group of fatty acids and ester. The similar band were identified by [11]. The absorption peaks in the regions of 1433 assigned to the $\mathrm{C}-\mathrm{H}$ bond is a characteristic feature of all alkyl group. In the area of 2241 and assigned to the $\mathrm{C}=\mathrm{C}$ bonds points to the presences of unsaturation within the alkyl chains. The band observed at $623 \mathrm{~cm}^{-1}$ also indicates mainly the presence of alkene functional. It was concluded that the presence of the different functional group of compounds and the $\mathrm{O}-\mathrm{H}$ broad peak is attributed to $\mathrm{O}$-H bonding with hydrocarbon contents, indicating the presence of carboxylic acid and ester in the extracted oil.

\section{Gas chromatography and mass spectrometry analysis}

The GCMS analysis of the extracted oil was carried to determine the constituent of the extracted CTS oil. The GCMS analysis separated the extracted oil mixtures into individual components and identified the various parts from their mass spectra. Figure 2 presents the chromatograph of the GCMS analysis of the extracted CTS oil.

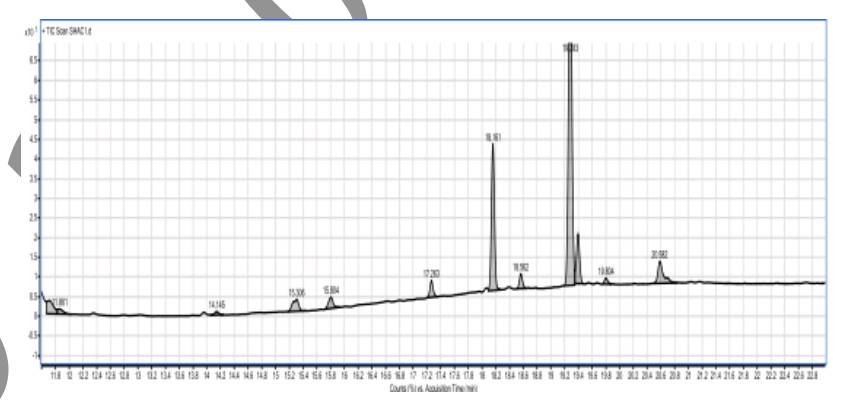

Figure 2 - Gas Chromatograph of CTS Oil

Table 3 shows the compounds identified and their percentage area compared to the chromatogram's total size, which estimates their relative concentration in the extracted oils. Table 3 shows that the extracted oil is a complex mixture with 12 identified compounds; the extracted oil contained mainly carboxylic acid.

Table 3 shows that the extracted CTS oil contains 12 fatty acids with $\mathrm{C} 13$ - C17 chain length, mainly Mono Unsaturated Fatty Acids (MUFAs) and Saturated Fatty Acids (SFAs). The GCMS analysis reveals the presence of 4 MUFAs and 8 SFAs compounds in the CTS oil. The total distribution of the MUFA constituent of the oil is $61.69 \%$ fatty acid, with Palmitoleic acid (C16:1 w7) accounting for $53.20 \%$ of the total Fatty acids, and Myristoleic acid (C14:1 w5) accounting for the least contributor at $0.63 \%$. Also, extracted oil was found to contain $38.31 \%$ SFAs, and the major contributor to SFA constituents is $19.32 \%$ Palmitic acid (C16:0) and the least being Iso-palmitic acid at $0.85 \%$. 
Table 3 - GCMS analysis of extracted CTS oil

\begin{tabular}{|c|c|c|c|c|c|c|c|}
\hline No & $\begin{array}{l}\text { Retention } \\
\text { time }\end{array}$ & Area & $\begin{array}{c}\text { Percentage } \\
\text { composition }\end{array}$ & $\begin{array}{l}\text { Carbon } \\
\text { number }\end{array}$ & Systematic name & Common name & $\begin{array}{c}\text { Molecular } \\
\text { Weight }\end{array}$ \\
\hline 1 & 11.70 & 20.63 & 3.76 & C13:0 & Tridecanoic acid & Tridecylic acid & 228 \\
\hline 2 & 11.86 & 6.63 & 1.20 & & & & \\
\hline 3 & 14.14 & 3.47 & 0.63 & C14:1w5 & $\begin{array}{l}\text { Tetradecenoic } \\
\text { acid }\end{array}$ & $\begin{array}{l}\text { Mysristoleic } \\
\text { acid }\end{array}$ & 240 \\
\hline 4 & 15.30 & 17.71 & 3.22 & C14:0 & $\begin{array}{l}\text { Tetradecanoic } \\
\text { acid }\end{array}$ & Myristic acid & 242 \\
\hline 5 & 15.80 & 12.63 & 2.30 & & & & \\
\hline 6 & 17.26 & 12.69 & 2.31 & Iso C15:0 & $\begin{array}{c}\text { Iso- } \\
\text { Pentadecanoic } \\
\text { acid }\end{array}$ & $\begin{array}{r}\text { Iso } \\
\text { Pentad } \\
\text { aci }\end{array}$ & \\
\hline 7 & 18.16 & 105.99 & 19.32 & C16:0 & $\begin{array}{l}\text { Hexadecanoic } \\
\text { acid }\end{array}$ & & 70 \\
\hline 8 & 18.56 & 10.93 & 1.99 & C16:1w11 & & & \\
\hline 9 & 19.28 & 291.82 & 53.20 & C16:1w7 & $\begin{array}{r}\text { cis- } \\
\text { Hexade } \\
\text { aci }\end{array}$ & mitoleíc & 268 \\
\hline 10 & 19.39 & 32.24 & 5.87 & C16:1w5 & & 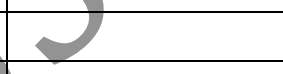 & \\
\hline 11 & 19.80 & 4.71 & 0.85 & Iso C16:0 & $\begin{array}{c}\text { Hexadecanoi } \\
\text { acid }\end{array}$ & $\begin{array}{l}\text { Iso-Palmitic } \\
\text { acid }\end{array}$ & 270 \\
\hline 12 & 20.58 & 29.55 & 5.38 & C17:0 & $\begin{array}{l}\text { Heptadecanoic } \\
\text { acid }\end{array}$ & Margaric acid & 284 \\
\hline
\end{tabular}

From Table 3, most of the fatty acid constituent is in the range of $\mathrm{C} 16-\mathrm{C} 17$ and constitute $86.61 \%$ of the extracted oil's fatty acid content. The MUFA constituent of $61.69 \%$ fatty acid and $38.31 \%$ SFA in the extracted oil are higher than $43.21 \%$ MUFA and $19.37 \%$ SFA reported by [5] for CTS oil. Table 11 shows that the main MUFA constituent in the extracted oil is Palmitoleic acid (53.20\%) compared to Oleic acid (43.21\%) reported by [5] for CTS oil. The difference in the MUFA type in the extracted oil and that reported by [5], could be attributed to factors such as species and strain of the plant, regional and climatic factors, degree of ripeness, harvest and storage method of the seeds, chemical refining process among others.

The validity of the fatty acid that was deduced from the chromatograph was affirmed by comparing it with other reports that have been made on the characterization of the fatty acid composition of the Cassia Tora plant. Five Fatty acids identified from the extracted CTS oil (Table 3) were also reported by $[1,7,19]$ for the Cassia Tora plant's leaves and stems.

\section{Physicochemical characterization of diesel, biodiesel-diesel blend and biodiesel}

The biodiesel produced from CTS oil and the combinations with petroleum diesel at different ratios were characterized to determine its physicochemical properties for its suitability for combustion engine use. Table 4 presents the physicochemical properties of diesel, biodiesel-diesel blend and biodiesel produced in study.

B0 $=100 \%$ petroleum diesel, $\mathrm{B} 5=5 \%$ Biodiesel and $95 \%$ petroleum diesel, B12.5 $=12.5 \%$ Biodiesel and $87.5 \%$ petroleum Diesel, B20 $=20 \%$ Biodiesel and $80 \%$ petroleum diesel and B100 $=100 \%$ Biodiesel.

The specific gravity, a measure of fuel oil's flowability, was determined for diesel, biodiesel-diesel blend and biodiesel. From Table 4, the specific gravity of the petroleum diesel (B0), which is 0.8718 is comparable to those of $\mathrm{B} 5(0.8744)$ and B12.5 (0.8764). In contrast, the specific gravity of $\mathrm{B} 20(0.8787)$ and B100 (0.9092) is slightly higher than that of petroleum diesel (B0). It can be seen that the specific gravity of B0, B5, B12.5, B20 and B100 are within the recommended EN14214 standard and BIS 15607 international average of 0.86-0.91 particular gravity for biodiesel fuel used in internal combustion engines $[12,15]$. 
Table 4 - Physicochemical properties of diesel, biodiesel-diesel blend and biodiesel

\begin{tabular}{|l|c|c|c|c|c|c|c|}
\hline \multicolumn{1}{|c|}{ Properties } & Unit & Diesel (B0) & B5 & B12.5 & B20 & B100 & Standard \\
\hline S.G & $15 / 4^{\circ} \mathrm{C}$ & 0.8718 & 0.8744 & 0.8764 & 0.8787 & 0.9092 & $0.86-0.91$ \\
\hline Colour & ASTM & 1.0 & 2 & 2.5 & 2.5 & 6.5 & 6 max \\
\hline Total Sulphur & \%wt. & 0.137 & 0.131 & 0.125 & 0.118 & 0.039 & $0.5 \mathrm{max}$ \\
\hline Viscosity @ $40^{\circ} \mathrm{C}$ & $\mathrm{cSt}$ & 4.99 & 4.38 & 5.13 & 6.17 & 20.6 & $1.9-6.0$ \\
\hline Cloud Point & ${ }^{\circ} \mathrm{C}$ & 4 & -3 & -4 & -4 & 7 & Varies \\
\hline BS\&W & $\%$ Vol. & & Trace & Trace & Trace & Trace & - \\
\hline Flash Point & ${ }^{\circ} \mathrm{C}$ & 96 & 85 & 80 & 75 & & 70 min \\
\hline Cetane Number & & 44 & 41 & 40 & 40 & 35 & 40 min \\
\hline Calorific Value & $\mathrm{MJ} / \mathrm{kg}$ & 43.2 & 42.83 & 42.45 & 41.7 & 39.5 & $38 \mathrm{~min}$ \\
\hline
\end{tabular}

Viscosity, a measure of the fuel spray atomization and fuel system lubrication was evaluated for the diesel, biodiesel-diesel blend and biodiesel samples. Table 4 shows that kinematic viscosity of B0 which is $4.99 \mathrm{cSt}$ is comparable to those of B5 (4.38 cSt), B12.5 (5.13 cSt) and B20 (6.17 cSt) while the viscosity of B100 which is 20.6 cSt was higher. The kinematic viscosity of B0, B5, B12.5 and B20 are within the recommended ASTM 6751 standard of 1.9-6.0 cSt and BIS 15607 international average of 2.5-6.0 cSt while the viscosity of B100 is much higher than the recommended standard for fuel used as diesel in internal combustion engines $[12,14$,$] . The high viscosity of the$ B100 indicates the need for blending of the CTS oil-based biodiesel with petroleum diesel to enhance its viscosity.

Flashpoint of a liquid is the minimum temperature at which the liquid gives sufficient vapours to ignite momentarily when a flame of standard dimension is brought near the liquid's surface. It is a measure of safety in the handling of fuel oil. Flashpoint of the diesel, biodiesel-diesel blend and biodiesel samples were also evaluated as shown in Table 4, the flashpoint of B0, B5, B12.5, B20 and B1 00 are within the recommended ASTM 6751 standard (minimum of $80^{\circ} \mathrm{C}$ ) and EN14214 standard (minimum of $70^{\circ} \mathrm{C}$ ) for fuel used as diesel in internal combustion engines $[12,14]$.

The calorific or heating value measured by the heat released during combustion of a specific amount of fuel was determined for the diesel, biodiesel-diesel blend and biodiesel samples. Table 4 shows that the calorific value, which is a measure of the fuel economy, was defined as $43.2 \mathrm{MJ} / \mathrm{kg}$ for B0 (petroleum diesel) while those of the blends are in the range of 39.542 .83 . The calorific value of B0, B5, B12.5, B20 and B100 are high and comparable to recommended ASTM 6751 standard, EN 14214 standard and BIS 15607 international standard of $38 \mathrm{MJ} / \mathrm{kg}$ minimum for fuel used as diesel in internal combustion engines $[12,14]$. The calorific value of the $\mathrm{B} 100(39.5 \mathrm{MJ} / \mathrm{kg}$ ) reported in this study is comparable to $39.79 \mathrm{MJ} / \mathrm{kg}$ [14] and $39.9 \mathrm{MJ} / \mathrm{kg}$ [10]. It was observed that the increase in biodiesel blending ratio results in a decrease in the blend's calorific value.

Cetane number, a measure of the ignition, smoking, and emission-quality fuel oil was determined for the diesel, biodiesel-diesel blend and biodiesel samples.

From Table 4, the cetane number of 44 obtained for B0 (petroleum diesel) is higher than those of $\mathrm{B} 5, \mathrm{~B} 12.5, \mathrm{~B} 20$ and B100, which are in the range of 35-44.

The obtained cetane number for B0, B5, B12.5 and B20 comparable to the minimum recommended value of 40 by ASTM D-6751 for fuel used as diesel in internal combustion engines while that of B100 is lower $[12,14]$. Hence B0, B5, B12.5 and B20 are suitable for use in combustion engines.

Cloud point is a measure of the temperature at which cloudy and wax formation in liquid fuel was observed. The cloud point for diesel, biodieseldiesel blends and biodiesel samples were determined as shown in Table 4 . The cloudy point of $4{ }^{\circ} \mathrm{C}$ and $7{ }^{\circ} \mathrm{C}$ obtained for B0 (petroleum diesel) and B100. It can also be seen that the cloud point for B5, B12.5 and B20 are much lower than those of $\mathrm{B} 0$ and B100. The cloud point of $-4^{\circ} \mathrm{C}$ obtained in this study for B12.5 and B20 is comparable to $6^{\circ} \mathrm{C}$ [2] and [12] for B20 biodiesel.

Total sulphur content, which is a measure of the corrosive tendencies of fuel, was evaluated. The total Sulphur for diesel, biodiesel-diesel blends and biodiesel samples were determined as shown in Table 4. The full sulphur B0 (petroleum diesel) is $0.137 \%$, higher than B5, B12.5, B20 and B100. However, the total Sulphur in B100 (0.039\%) is 
well below the recommended minimum value of $0.05 \%$ by ASTM D6751 for fuel used as diesel in internal combustion engines [2], while that of B0, B5, B12.5 and B20 are higher. Furthermore, the fuel colour for diesel, biodiesel-diesel blends and biodiesel samples was determined and found within the ASTM D-6751 recommended value of 3 maximums [14]. It was observed that B0, B5, B12.5 and B20 are within recommended colour value except for B100 with the higher colour value of 6 . Hence, from the physicochemical properties of the diesel, biodiesel-diesel blends and biodiesel samples presented in Table 4, it can be concluded that B5, B12.5 and B20 are within acceptable limit except for B100 which would require upgrading to meet up with the recommended standard for fuel used as diesel in internal combustion engines.

\section{CONCLUSION}

The physiochemical characterization showed that 5, 12.5 and $20 \%$ CTS oil-based biodiesel-diesel blends are within acceptable combustion engine without modification except for $100 \%$ CTS oilbased biodiesel which would require upgrading to meet up with the recommended standard for fuel used as diesel in internal combustion engines. FTIR and GCMS analysis shows the functional groups and characteristic peaks of fatty acids and methyl ester with carbon range from $\mathrm{C} 13-\mathrm{C} 17$ with $\mathrm{C} 16$ constituting the major fatty acid group and contains $61.69 \%$ MUFA and $38.31 \%$ SFA with a $94.3 \%$ biodiesel yield.

\section{REFERENCES}

1. Alao, F. O., Ololade, Z. S., \& Nkeonye, C. V. (2018). Phytochemical and Antibacterial Potentials of Senna tora Leaf and Seed Extracts against Some Clinically Isolated Bacteria. Journal of Bacteriol Parasitol, 9(3), 14.

2. Bjorn, S. S., Sergio, C. C., \& Jewel, A. C. (2013). Engine Performance and Exhaust Emissions of Peanut Oil Biodiesel. Journal of Sustainable Bioenergy Systems, 3, 272-286.

3. Jain, S., \& Patil, U. K. (2010). Phytochemical and pharmacological profile of Cassia tora Linn. - An Overview. Indian Journal of Natural Products and Resources, 1(4), 430-437.

4. Kumar, V., \& Roy, B. K. (2018). Population authentication of the traditional medicinal plant Cassia tora L. based on ISSR markers and FTIR analysis. Scientific Reports, 8(1). doi: 10.1038/s41598018-29114-1

5. Mankilik, M., \& Mhya, D. H. (2014). Preliminary Study on Physiochemical and Fatty Acids Content of Cassia tora Seed Oil. International. Journal of Pharmacognosy and Phytochemical Research, 6(2), 176-178.

6. Mosesane, J., Mbaya, K., Tshabalala, R., \& Kalombo, L. (2015). Characterization of Fuel Properties for the Biodiesel-Petro-Diesel Blends Dosed with the FPC. Global Journal of Researches in Engineering: General Engineering, 15(4), 1-7.

7. Mostafa, N., Bishr, M., Singab, A. N., \& Salama, O. (2015). Phytochemical and Biological Evaluation of Cassia tora, L.Seeds. Journal of Pharmacy and Biological Sciences, 10(1), 1-8.

8. O'kuru, H. R., Payne-Wahl, K. L., \& M., B. (2012). Medicinal Components Recoverable from Sicklepod (Senna Obtusifolia) Seed: Analysis of Components by HPLC-MSn. Journal of Chromatography Separation Techniques, 1, 1-4.

9. Otadi, M., Shahraki, A., Goharrokhi, M., \& Bandarchian, F. (2011). Reduction of Free Fatty Acids of Waste Oil by Acid-Catalyzed Esterification. Procedia Engineering, 18, 168-174.

10. Othman, M., Abdullah, A. A., Kamal, K., Asri, S., Azmi, Z., \& Mamat, R. (2019). Improvement of fuel properties for palm oil methyl ester (POME) biodiesel blends using organic germanium as additives. IOP Conference Series: Materials Science and Engineering, 469, 012121. doi: 10.1088/1757-899x/469/1/012121

11. Pawar, H. A., \& Lalitha, K. G. (2015). Extraction, Characterization, and Molecular Weight Determination of Senna tora (L.) Seed Polysaccharide. International Journal of Biomaterials, 20(15). 
12. Qasim, M., Ansari, T. M., \& Hussain, M. (2017). Combustion, Performance, and Emission Evaluation of a Diesel Engine with Biodiesel Like Fuel Blends Derived From a Mixture of Pakistani Waste Canola and Waste Transformer Oils. Energies, 10(7), 1023. doi: 10.3390/en10071023

13. Radoslav, M., Milan, T., Ferenc, M., Ferenc, K., Mirko, S., \& Aleksandra, A. (2018). Reduction of free fatty acids in waste oil for biodiesel production by glycerolysis: investigation and optimization of process parameters. Green Processing and Synthesis, 8(1), 1-21.

14. Ramesh, B. N., \& Appa-Rao, B. V. (2013). Performance Evaluation of Caster Methyl Ester in Direct Injection Four Stroke Diesel Engine. Global Journal of Engineering, Design and Technology, 2(6), 22-28.

15. Ridha, B. S., Mounir, B., \& Manef, A. (2015). Waste Frying Oil with High Levels of Free Fatty Acids as one of the prominent sources of Biodiesel Production. Journal of Mater and Environmental Science, 6(4), 1178-1185.

16. Röttig, A., Wenning, L., Bröker, D., \& Steinbüchel, A. (2009). Fatty acid alkyl esters: perspectives for production of alternative biofuels. Applied Microbiology and Biotechnology, 85(6), 1713-1733. doi: $10.1007 / \mathrm{s} 00253-009-2383-z$

17. Saifuddin, N., Samiuddin, A., \& Kumaran, P. (2015). A Review on Processing Technology for Biodiesel Production. Trends in Applied Sciences Research, Centre for Renewable Energy: Malaysia, 10(1), 1-37.

18. Sharma, V. K., Yngard, R. A., \& Lin, Y. (2009). Silver nanoparticles: Green synthesis and their antimicrobial activities. Advances in Colloid and Interface Science, 145(1-2), 83-96. doi: 10.1016/j.cis.2008.09.002

19. Shukla, S. K., Kumar, A., Terrence, M., Yusuf, J., \& P., S. V. (2013). The Probable Medicinal Usage of Cassia Tora: An Overview. Journal of Biological Science, 13, 13-17.

20. Singh, V. K., \& Khan, A. M. (2009). Medicinal Plants and Folklores - A Strategy towards Conquest of Human Ailments. N. d. : Today and Tomorrow Printers and Publishers.

21. Sivaramakrishnan, K., \& Ravikumar, P. (2012). Determination of cetane number of biodiesel and it's Influence on physical properties. ARPN Journal of Engineering and Applied Sciences, 7, 205-211.

22. Umar, I. A., Aroke, U. O., \& Osha, O. A. (2018). Response surface methodological optimization of biodiesel production from cassia tora seed. ABUAD Journal of engineering research and development, 1(2), 49-63.

23. Usman, M. A., Olanipekun, 0. O., \& Henshaw, U. T. (2012). A Comparative Study of Soya Bean Oil and Palm Kernel Oil as Alternatives to Transformer Oil. Journal of Emerging Trends in Engineering and Applied Sciences, 3(1), 33-37. 